I am not discouraged or despondent over the re-employment figures in the mining industry. I take consolation that many men are fit and well and fully occupied with outside interests, including sport. The fact that they do not come on a pay roll is scarcely relevant.

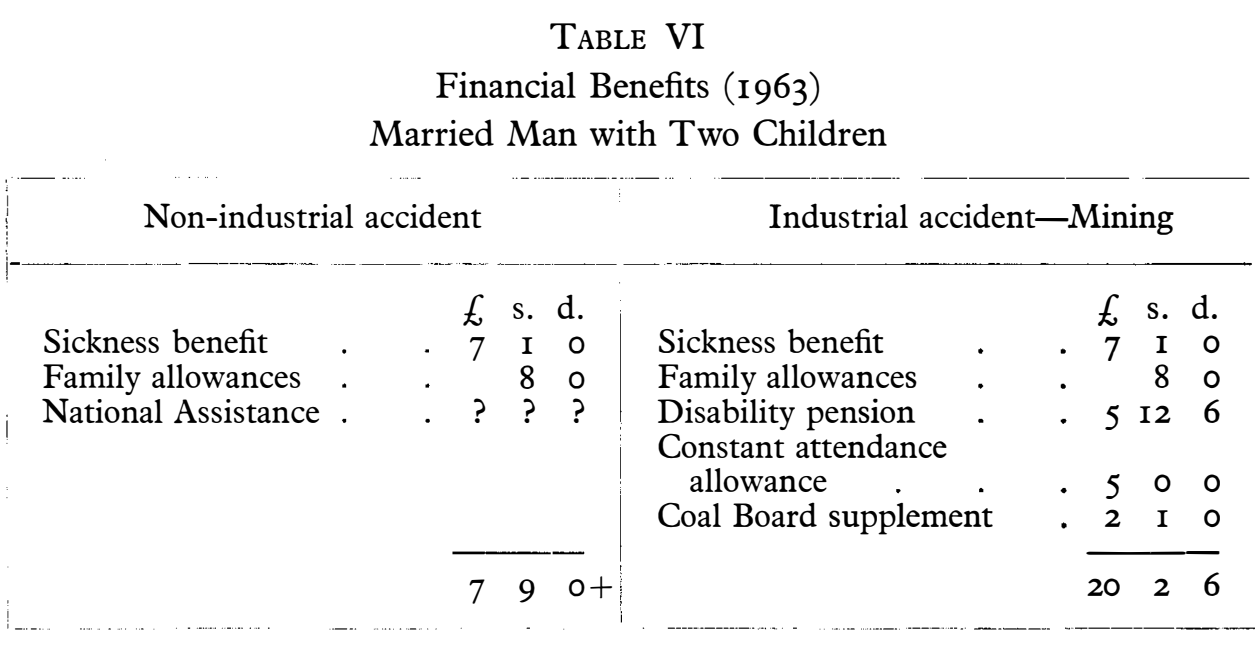

REFERENCE

Nicoll, E. A. (1946). Report to Miners' Welfare Commission.

\title{
SOCIAL ASPECTS OF PARAPLEGIC COAL-MINERS IN GERMANY
}

By F.-W. MEINECKe, M.D.

Abteilung für Rückenmarksverletzte, Chirurgische Klinik der Berufsgenossenschaftlichen Krankenanstalten 'Bergmannsheil', Bochum, Germany

GERMANY has a system of compulsory insurance. It consists of the following:

Legal Accident Insurance. Every employee is insured against injuries occurring on the way to work, at the place of work or on his way home from work, as well as against diseases acknowledged as occupational diseases. The insurance premium is paid exclusively by the employer. An income limit for this insurance does not exist. It is furnished by the Employers' Liability Insurance Associations.

Health Insurance. It provides for payments (doctor's fees, hospital treatment, medicaments, sick benefit, etc.) for all health damages to the insured or his family that have not occurred during the activities stated above. The insurance premium is paid half by the employer and half by the employee. Office workers with a monthly salary of more than I250,- DM and workers with more than $660,-$ DM monthly income are not included in this insurance scheme. 
Social Insurance. Provides for pensions in case of occupational disability and inability to make a living. The fees have to be paid half by the employer and half by the employee. This insurance is obligatory for all workers and for office workers up to a monthly income of I250,- DM.

In the coal-mining industry the 'Bergbau-Berufsgenossenschaft' (Mutual Accident Insurance Association of the Mining Industry) furnishes the Legal Accident Insurance and the 'Knappschaft' (Miner's Compensation Association) furnishes Health and Social Insurance. Private accident liability insurances do not have to be considered here, as they are not within the scope of this paper.

In order to survey the social situation of paraplegic coal-miners in Germany we have reviewed 269 files of the Bergbau-Berufsgenossenschaft, Bezirksverwaltung, Bochum. A selection under any one particular aspect has not been made in order to avoid a one-sided presentation. From this a certain incompleteness results, as in some of the files certain data were missing. In this presentation we quote only our actual findings.

I am very much indebted to the Bezirksverwaltung der Bergbau-Berufsgenossenschaft, Bochum, for the generous assistance and technical advice given in compiling this paper.

The injured referred to here are insured exclusively by the Bergbau-Berufsgenossenschaft, Bezirksverwaltung, Bochum. The results do not allow any conclusions with regard to the conditions of all paraplegics insured by an Employer's Liability Insurance Association. The general situation of those not insured with an Employer's Liability Insurance Association differs even more from the conditions presented here, but these cases are not within the scope of our subject. The files surveyed in this paper contain II 4 cases of complete and I55 cases of incomplete paraplegia.

\section{The Employers' Liability Insurance Associations provide}

(a) Curative Treatment. It comprises medical treatment, supply of medicaments, nursing and orthopaedic devices and appliances, as well as attendance. Treatment is generally given in the department for spinal cord injuries in the Berufsgenossenschaftlichen Krankenanstalten 'Bergmannsheil' in Bochum, a hospital belonging to the Mutual Accident Insurance Association for the Mining Industry. In addition, there are nine further departments of different sizes in the Federal Republic of Germany, all of them belonging to the Employers' Liability Insurance Associations. A patient who is not insured would have to pay for treatment in the lowest nursing class from about 900,- to I000,- DM per month while the actual costs might be still higher.

(b) Payment to the Insured. It is paid during the time of inability to work up to the first payment of pension. If the patient is not hospitalised he receivesdepending on his family status-up to 75 per cent. of his regular wages.

(c) Disability Pension. It commences with the day after the cessation of the inability to work.

232 workers receive a monthly disability pension averaging $465,-\mathrm{DM}$, 8 employees receive $780,-\mathrm{DM}$. The lowest pension for labourers is a monthly payment of $270,70 \mathrm{DM}$, the highest $713,30 \mathrm{DM}$. For employees these figures range between 526,40 and I I $81,20 \mathrm{DM}$. 
(d) Family Allowance. If the reduction of working capability is estimated at 50 per cent. or more, the injured gets a family allowance of io per cent of the disability pension for each child up to the age of 18 , and for each child still going to school or during professional training up to the age of 25. It is increased to $25^{-} \mathrm{DM}$ for the second child and is further increased by steps for each further child up to $70,-$ DM.

(e) Attendance Allowance. If there exists dependence on help in accordance with the German social legislation, an attendance allowance of IOO,- DM up to $350,-\mathrm{DM}$ is paid per month. The amount depends on the degree of the person's dependence on help and on his general state of health (paralysis of the bladder and bowels, bedsores, severe damage to the urinary tract, etc.). Of 243 cases, there are at present 206 who receive attendance allowances, and of these 2I receive IOO,- DM, 83 receive $260,-\mathrm{DM}$ and 6 receive $350,-\mathrm{DM}$ per month. In cases where dependence on help is not present-e.g. in cases of slight bladder and bowel troublea monthly allowance of 25,- DM can be paid for increased use of linen and washing agents.

The total monthly income consisting of disability pension, family allowance and attendance allowance therefore amounts to sums which in the majority of cases fall between 500,- and 1000,- DM. This fact will be mentioned again later.

(f) Pension for Widows and Orphans, Death Allowance. If the insured dies immediately or later as a result of the accident, the widow receives for a further three months the full pension without family and attendance allowances, as transitional allowance. After this period, $\frac{3}{10}$ to $\frac{2}{5}$ of the annual wages are paid, taking into consideration age and number of children. In addition, each halforphan receives $\frac{1}{5}$ and each full orphan $\frac{3}{10}$ of the annual salary as monthly pension.

The death allowance is paid only once and amounts to ${ }_{1}^{1} \frac{1}{2}$ of the annual salary but not less than 400,- DM.

Social Insurance. To complete the picture of the financial situation, it is necessary to deal with the occupational or old-age pension. It is paid by the Miners' Compensation Association. It is not possible to give exact figures here because the basis of calculating this benefit is changed annually. In case of incapacity for work, the old-age pension paid by the Miners' Compensation Association, together with the accident pension (without family and attendance allowance), may amount to the annual salary earned in the year preceding the accident. The number of years of insurance forms the basis for calculating the pension. The amounts are, therefore, subject to wide variations.

The total monthly income of our miners from payments by the Legal Accident Insurance and the Miners' Compensation Association may vary between 700,- and I000,- DM in the majority of cases. An employee may receive an income up to I500,- DM and more. The whole income is tax-free.

Appliances. The Mutual Accident Insurance Association for the Mining Industry provides the following appliances (table I)

In addition, the insurance association pays for the repair of aids and appliances and for the renewal. This work is taken over by the 'Kunstgliederbeschaffungsabteilung' (department for the supply of artificial limbs) in co-operation with our 


\begin{tabular}{ll}
\multicolumn{2}{c}{ TABLE I } \\
\multicolumn{1}{c}{ Aids, Appliances, Dressings, etc., for Paraplegics } \\
I wheelchair & I blanket \\
I cushion & I bedpan with air cushion \\
I back cushion & I irrigator with rubber tube and \\
I pair of calipers & rectal tube for enemas \\
I pair of orthopaedic shoes & 4 woollen sheets \\
I pair of crutches & I rubber sheet \\
2 rubber urinals & 2 urine bottles \\
2 abdominal belts & Tissue paper \\
I foam rubber matress & Gauze \\
4 millet bags & Disinfectant solution \\
I sandbag & Alcohol \\
I bed support & Soap \\
I bed pole & Spa Water \\
I foot support &
\end{tabular}

Total cost: $3.253-\mathrm{DM}$

own workshop for artificial limbs. Both services co-operate closely with the department 'Berufshilfe' (occupational assistance) and complement each other very well. Each paraplegic is visited at least once a year by an official of these departments, but more frequent visits are possible if this is requested by the patient.

Occupational Assistance. It is the task of this service to give assistance to the injured in securing his former place of work or in getting a new one suitable for him. The new job has to be as equal to the former as possible. How far this objective can be achieved will be discussed later. The guiding principle, however, is that the decision lies with the discretion of the representative of the insurance association, who takes into account all that is necessary to resotre the working capacity of the injured as soon as possible.

Occupational welfare begins at the bedside with informative talks and the early introduction of the necessary measures. If it is not possible for the paraplegic to return to his former job, there is the possibility of providing a partly skilled job or of starting advanced training in the former skill to secure a new working place or to re-train altogether. As the Accident Insurance Association pays a training allowance to the partly skilled worker amounting to 40 per cent. of the standard wages, the employer has to pay only 60 per cent. However, the period for this allowance is limited.

In the case of advanced vocational training and re-training, the costs incurred (books, educational material, etc.) are refunded, and maintenance is paid up to the amount of the full pension, should a regular income not exist. In addition, costs for tools and appliances can be accepted.

Transport. Special allowances are paid to paraplegic miners for the purchase of a motor car, which can be as high as $800,-\mathrm{DM}$, instead of supplying a self-propelled outdoor wheelchair. In addition, the cost of converting the car into a manually operated one is paid. If the injured person is employed he receives a further allowance. These special allowances do not have to be paid back. 
For the purchase of a car, the paraplegic can under certain circumstances, obtain advances on his pension which have to be paid back in instalments. Otherwise, a self-propelled outdoor wheelchair is supplied free on request.

Housing. The Mutual Accident Insurance Association, in collaboration with the mines, tries to obtain suitable housing for the paraplegic. Here, local building societies are called upon to co-operate. The aim is to obtain a flat on the ground floor with sufficient space and bath. Alterations to the building are often necessary and include adding a ramp for the wheelchair, installing bath and toilet appliances, widening the door-frames and providing a parking space for the self-propelled outdoor wheelchair. In general, the expenses are refunded by the Berufsgenossenschaft where these changes are necessary on account of the paraplegia.

Compensations. Finally, the possibility of compensation must be mentioned. It can be granted for building purposes, for the purchase of property and for starting a new professional career.

Results. There is no doubt whatsoever that the paraplegic miner has no financial hardship. The total income he receives from the Legal Accident Insurance Association and the Miners' Compensation Association ensures a comfortable living for him and his family. After death resulting from the accident, his widow and those children entitled to maintenance are also taken care of.

However, this good pension does have certain drawbacks with regard to his industrial resettlement. It is very often a serious obstacle to re-employment, as there is no urgent need to improve the financial situation. There are, of course, other reasons which also contribute to this problem, and I should like to mention at least one point here. Taking up work again is quite often impossible because employer and personnel are not willing, on account of the paraplegic's high pension, to provide a job for him which could be held by a person who is less disabled and receives a correspondingly smaller pension. There is no need to describe here how much trouble, patience, endurance and time is needed to find employment for a paraplegic. Our vocational advisers do their best, but they very seldom succeed.

\section{TABLE II}

designing enginneer

textile engineer

technical employee

fiscal officer

book-keeper

watch-maker

tailor

carpenter

plumber

specialist carpenter and wood-worker

machine operator

craftsman

social worker

draughtsman in surveyor's office

electro-technician merchant

clerical worker

chicken farmer

telephone operator

door-man

park attendant

bicycle park attendant

knitter

waggon cleaner

bath attendant

rail cleaner

storeman

woodcutter

unskilled labourer

looking after the household (wife employed) 
For understandable reasons, it is less difficult to find work for an office worker than for a manual worker. Thus, all 8 employees out of the group in question are working again or will take up work in the near future. Out of 247 cases of this survey, I8 paraplegics have full-time work (I I of these have a disability of Ioo per cent., 7 have one of less than Ioo per cent. Eleven paraplegics have part-time work (Io of these have a disability of Ioo per cent., I of less than Ioo per cent.). Thirteen paraplegics do home work (I I of these have an estimated disability of Ioo per cent., 2 of less than 100 per cent.). That makes a total of 42 paraplegics with either fulltime or part-time work. Fifteen paraplegics had been working temporarily, 7 cases are not yet completed.

Of those insured, I94 who are not yet working belong to the group with a disability of 100 per cent. Thirty different jobs were found among those paraplegics who are working. They are listed in the table II, above.

The personal conditions of life are characterised by the following: Of a total of 269 insured, 47 files contained no data as to housing conditions. 2 of the remaining 222 paraplegics are living in a nursing home.

I 5 I have flats on the ground floor
$25 \%, \%, "$, first floor
$6 \%, \%$,, second floor
$6 \%$,, third floor
32 own a house

Of the paraplegics, I 44 are known to have bathrooms. But here, too, the files are not complete, so that this figure will certainly be higher.

The fact that II 3 of the paraplegics in question own a motor car adds to the overall picture of the situation. A car is a great help to the paraplegic. Its purchase and upkeep, however, require financial sacrifices on the part of the disabled, despite the allowances he is entitled to and despite the fact that he does not have to pay motor vehicle tax. I am sure that still more paraplegics own a car, as some of the files did not contain complete data. Thirty-eight patients have motorized wheelchairs.

Family Situation. Family life is of particular importance for a disabled person. Of the 269 paraplegics, I 87 were already married before the accident, 34 married after the accident, 38 remained single. Seven paraplegics were divorced after the accident. This fact alone is reason enough to do everything possible to bring the patient back to his family as soon as possible in a good state of health. This is the more urgent when there are children waiting for their father. Before the accident, I 42 injured already had children, I 6 patients had their first child after the accident, I 8 had children in addition to others born before the accident. This makes a total of 34 cases whose children were born after the paraplegia. Twelve have fosterchildren and 8I have no children at all. Everyone of experience knows how very much children tie up a marriage which is often exposed to a great strain.

Psychological Aspects. A short glance at the personal behaviour of the injured may conclude this survey. In only 35 cases was addiction registered-an addiction related to narcotics in most cases. Therefore, the doctor concerned should always 
ask himself whether the prescription of such medicaments is really indispensable. We have not used any narcotics for many years and have successfully treated paraplegics with drug addiction. There are 6 alcoholics among the patients in question, but they should not present a percentage much above that of the general population. Only one case of attempted suicide is mentioned in our files-a fact which very clearly points out that the injured have adjusted themselves quite well to their new conditions of life.

In conclusion, one can reasonably say that the German paraplegic miner meets with good conditions in life. He receives a satisfactory income and is given the opportunity, by way of allowances and advances, to obtian a flat or house suited to his needs. All kinds of aids and appliances are put at his disposal and he is also well cared for after the completion of hospital treatment. A paraplegic is very rarely put in a nursing home. Divorces are just as rare.

The results of our attempts to re-integrate the paraplegic miner into our working life are rather depressing. Here, many tasks lie ahead of us. But, as in other fields, we must not relax in constantly trying to improve the social situation of these most severely disabled persons.

\title{
THE PARAPLEGIC PATIENT AS A SOCIAL PROBLEM
}

\author{
By M. Damanski, M.D. \\ Liverpool Regional Paraplegic Centre, Promenade Hospital, Southport, Lancashire
}

THE social significance of a paraplegic patient's disability can be fully understood only if his personal background, age, circumstances of the injury, income and the facilities for domestic resettlement and re-employment are given adequate consideration. This is the purpose of this paper, which is based on the study of 300 paraplegic patients admitted to the Southport Centre over the period of 17 years.

The area covered by this Centre is made up of coal-mining regions, concentrations of heavy and light industry, and agricultural communities, all conected by brsy overland communication lines and served by two large ports. It contains las cities with their complicated social structure, medium-sized and small towns, and villages. It can, therefore, be assumed that the patients studied represent a true cross-section of all the social classes and their related physical hazards in this country and perhaps those of any other country with a similar economic structure.

Age of Patients. Table I gives an idea of the age of the patients. It is clear that the incidence is highest in the third and fourth decades of life, and these paidancs constitute about hali the total number of paraplegic patients.

Circumstances of Spinal Injury. Table II gives an idea of the circumstances of spinal injury. The hazards described as industrial account for about so per cent. of paraplegia. Mainly manual workers, skilled and unskilled, lacking an adequate educational background to enable them to switch over to office work, they live with their large families, often in cld and primitive houses, with inadequate saritation, etc. Althovgh they may have been earning a substantial income, they do at appear to have acquired the habit of saving for a rainy day. An accidentinsurance policy is rather the exception than the rule. 